\title{
Effects of pattern of concentrate feeding on milk production of dairy cows offered silage ad libitum
}

\author{
Y. S. RIJPKEMA', L. VAN REEUWIJK ${ }^{1} \&$ P. W. GOEDHART ${ }^{2}$ \\ 1 Research Institute for Livestock Feeding and Nutrition, P.O. Box 160, NL 8200 AD \\ Lelystad, Netherlands \\ 2 Agricultural Mathematics Group, P.O. Box 100, NL 6700 AC Wageningen, Netherlands
}

Received 6 February 1990; accepted 14 March 1990

\begin{abstract}
In three 24-week experiments beginning at week 4 post partum, a system of concentrate feeding at a flat level was compared with feeding concentrates to milk yield (Experiments 1 and 2), or with a high-low 2-step system in which the rate was reduced after week 12 (Experiment 3 ). Roughage was offered ad libitum. In Experiment 1 two types of concentrates were involved whereas in Experiment 3 two levels of concentrates were applied. The systems were evaluated with high levels of concentrates and with Friesian and Holstein-Friesian cows producing about $7000 \mathrm{~kg}$ milk per lactation. Experiments 1 and 3 involved 64 and Experiment 232 cows. In the comparison between feeding strategies, differences in yield and composition of milk were of minor importance except for milk protein content on the moderate quality grass silage diet (Experiment 1). Milk production tended to be higher for concentrates including fishmeal, in contrast to soybeanmeal, particularly so in the first half of the experimental period. However, milk fat content was significantly lower resulting in similar productions of $4 \%$ fat-corrected milk (4 \% FCM). Extra concentrates in Experiment 3 had significant positive effects on production of milk, fat and protein, and also on milk protein content and body weight gain. Feeding strategy however was without any significant effect. It was concluded that with high yielding cows, offered roughages to appetite, there is no need to feed concentrates strictly to their estimated individual energy requirements. This may be of increasing importance when forage allowances per cow increase as a consequence of smaller number of cows per farm.
\end{abstract}

Keywords: dairy cows, feeding strategy, flat level feeding, fish meal

\section{Introduction}

Since the studies of Broster and coworkers (Broster et al., 1969; Broster, 1972; Broster et al., 1975; Johnson, 1977) much attention has been given to a feeding strategy, which aimes at a high peak yield in early lactation. Crucial in these experiments was the residual effect of a high peak yield, as determined by the level of feeding in the first few weeks of lactation, on the milk production in mid and late lactation. Extra concentrates in early lactation, resulted in a residual effect on milk yield 
of 2.3 to 4.0 times the direct effect obtained during the period of application of the extra feed itself (the first 8 to 12 weeks of lactation). So, extension services advised and farmers accustomed to increase the feeding level after calving by enlarging the quantity of concentrates persistently, holding on till energy input balanced energy output.

However, the genetic potential for milk production increased during the years and so did peak production. Accordingly, high levels of concentrates were offered, depressing the intake of roughage, and increasing the frequency of low milkfat syndrome or problems with animal health such as going off feed. At the same time some doubts arose as to whether the residual effect of high peak yields was always as large as indicated by the experiments of Broster et al. (Gordon, 1976; Gordon, 1977; Steen \& Gordon, 1980a, 1980b). It was realized that in Brosters' experiments, cows were stall-fed on individual rations. Moreover, the amount of roughage (mostly hay) was restricted and feeding level was varied by varying the level of concentrates. So there was no compensation in roughage intake possible when concentrate levels were compared.

It was further realized, that in most of the newer buildings for housing cows and handling feeds it is not possible to feed roughage individually. Therefore, in these circumstances, an estimate has to be made for roughage intake of individual cows, and it is well known that such estimates are far from precise.

With this background in mind it was worthwhile to investigate, to which extent it is necessary to feed cows concentrates strictly to their individual requirements, calculated on basis of their actual milk production.

Østergaard in Denmark compared different strategies of feeding equal amounts of concentrates during the first half of the lactation to dairy cows, with forage or forage-like feeds ad libitum (Østergaard, 1979). He found substantial reductions in voluntary intake of grass silage, particularly when high levels of concentrates were fed. Moreover, he established that different patterns of feeding the same amount of concentrates during a long time of the lactation period, resulted in a similar total milk yield during that period. Diets and milk production were typical for Danish circumstances at that time.

In 1979 we decided to select one of Østergaards' strategies (flat level feeding of concentrates), and to compare this strategy with the more conventional way of 'feeding concentrates according to actual milk production' in two feeding trials. In another experiment, flat level feeding was compared with a more 'schematic' standard feeding (step feeding). These studies were initiated to examine the effects with cows and diets, which were more typical for the Dutch circumstances, i.e. cows yielding $6000-7000 \mathrm{~kg}$ of milk per year, and diets of grass silage (or a mixture of grass/maize silage) plus commercial compound feeds.

\section{Materials and methods}

\section{Experiment 1}

Sixty-four autumn calving, multiparous Friesian and Friesian-Holstein crossbred 
Table 1. Ingredient content of concentrate mixtures in the three experiments $\left(\mathrm{g} \mathrm{kg}^{-1}\right)$.

\begin{tabular}{lcccc}
\hline & \multicolumn{2}{l}{ Experiment } & 2 & 3 \\
\cline { 2 - 5 } & 1 & & & \\
\cline { 2 - 4 } & Soya & Fish & & \\
Soyabeanmeal (extracted) & 126 & - & 126 & 102 \\
Fish meal & - & 90 & - & - \\
Palmkernel expeller & - & - & - & 125 \\
Linseed expeller & - & - & - & 75 \\
Maize glutenfeed & 200 & 200 & 200 & 250 \\
Hominy feed (extracted) & 166 & 200 & 166 & - \\
Tapioca meal & 150 & 150 & 150 & - \\
Beet pulp & 150 & 150 & 150 & 217 \\
Citrus pulp & 97 & 97 & 97 & - \\
Wheat middlings & - & - & - & 80 \\
Soybean hulls & 70 & 70 & 70 & - \\
Cane molasses & 21 & 23 & 21 & 26 \\
Tallow & 20 & 20 & 20 & \\
Minerals, vitamins & & & & \\
\hline
\end{tabular}

pregnant cows were used in the first experiment, which lasted for 24 weeks. All cows came from the institute's dairy herd. At the end of the dry period they were randomly allocated to one of two groups receiving different concentrates. The first group, denoted by Soya, was fed a concentrate mix with soyabeanmeal as the main protein source. The second group, denoted by Fish, received concentrates in which fishmeal (with protein of low rumen degradability) accounted for a substantial part of the protein ${ }^{1}$. Difference in protein source was introduced to look for possible effects of rumen protein degradability on milk production. Ingredient composition of the concentrates is shown in Table 1.

In the second last and last week prior to the expected calving date all cows received 1 respectively $2 \mathrm{~kg}$ of concentrates per day. In the first, second and third week post partum, the level of concentrates was gradually increased, up to respectively 6,9 and $11.5 \mathrm{~kg} \mathrm{~d}^{-1}$. In the third week after calving the Soya and Fish group were subdivided in two treatment groups, denoted by standard and flat. For flatcows the level of $11.5 \mathrm{~kg}$ concentrates per day was sustained up to the end of the experiment at week 24. Standard-cows, however, were fed concentrates according to their net energy requirements (VEM = Dutch feed unit for milk: van Es, 1978; CVB, 1979), using a scheme shown in Table 2. Quantity of concentrates $\left(\mathrm{kg} \mathrm{d}^{-1}\right)$ was calculated after subtracting the individual VEM-intake as roughage from the total VEM-requirement of the individual cow. For all cows $1 \mathrm{~kg}$ of the daily amount

\footnotetext{
I Courtesy Dr I. H. Pike and the International Association of Fish Meal Manufacturers (IAFMM).
} 
Table 2. Scheme for the estimation of VEM-requirements of S-standard and F-standard cows from week 4 post partum onwards in Experiments 1 and 2.

\begin{tabular}{|c|c|c|}
\hline Week & $\begin{array}{l}\text { VEM-requirement based on } \\
\text { maintenance plus... }\end{array}$ & $\begin{array}{l}\text { Extra allowance } \\
\text { ( } \mathrm{kg} \text { concentrates) }\end{array}$ \\
\hline 4 & $\begin{array}{l}\text { milk (kg d-1) in week } 3 \text { and assuming fat } \\
\text { content to be } 4 \%\end{array}$ & 1 \\
\hline 5 & $\begin{array}{l}\text { milk }(\mathrm{kg} \mathrm{d}-1) \text { in week } 4 \text { and fat content } \\
(\%) \text { in week } 3\end{array}$ & I \\
\hline 6 & $\begin{array}{l}\text { milk }\left(\mathrm{kg} \mathrm{d}^{-1}\right) \text { in week } 5 \text { and fat content } \\
(\%) \text { in week } 4 \text {, but total VEM } \mathrm{d}^{-1} \text { not } \\
\text { below that in week } 5\end{array}$ & - \\
\hline 7 and 8 & $\begin{array}{l}\text { mean milk in week } 5 \text { and } 6\left(\mathrm{~kg} \mathrm{~d}^{-1}\right) \text { and fat } \\
\text { content }(\%) \text { in week } 5 \mathrm{a}\end{array}$ & - \\
\hline $\mathrm{N}$ and $\mathrm{N}+1$ & $\begin{array}{l}\text { mean milk in week N-2 and } \mathrm{N}-3\left(\mathrm{~kg} \mathrm{~d}^{-1}\right) \\
\text { and fat content }(\%) \text { in week } \mathrm{Na}\end{array}$ & - \\
\hline
\end{tabular}

a No larger change than 940 VEM (the equivalent of $1 \mathrm{~kg}$ of concentrates) per fortnight.

of concentrates was fed in the milking parlour $(0.5 \mathrm{~kg}$ at each milking). To all cows prewilted grass silage was offered ad libitum (about $5 \%$ orts).

Cows were housed in a freestall barn, and individually fed twice a day with roughage (at about $6.00 \mathrm{a} . \mathrm{m}$. and $3.00 \mathrm{p} . \mathrm{m}$.) and concentrates (after milking at $6.30 \mathrm{a} . \mathrm{m}$. and 3.30 p.m.) through Calan Broadbent gates, with the individual amounts offered and refused recorded daily. They were milked twice a day in a rotary parlour with milk weights recorded at 4 consecutive milkings per week. Milk samples were collected for each cow seperately at each recorded milking. Samples were analysed for fat and protein. Body weight was recorded on 2 consecutive days in the first week after calving, and once every week (same day, same time) up to week 24 .

Cows showing signs of mild clinical mastitis were treated by the cowmen with intramammary infusion of antibiotics. If clinical signs were more severe then cows were presented for examination by the veterinary surgeon.

Concentrate mixtures were sampled weekly throughout the experiment. Samples from each batch were combined into two composite samples for analysis of dry matter (DM), crude protein (CP), crude fibre (CF), ether extract and ash. Silage was sampled twice a week for analysis of DM. Dried samples were pooled into two composite samples for each clamp for analysis according to the Weende system and for in vitro organic matter digestibility (Tilley \& Terry, 1963).

Variables were statistically analysed by analysis of variance, assuming a completely randomised design with treatment factors Concentrate (soyabeanmeal and fishmeal) and Strategy (standard and flat). The average level for the first 3 weeks after calving was used as a covariable, except for body weight gain. 


\section{Experiment 2}

For this experiment, which lasted 24 weeks, 32 cows (no primiparous) were selected from the institute's herd. After calving they were randomly assigned to either of two groups: Soya-standard and Soya-flat. They were fed a concentrate mix with soyabeanmeal as the main protein source. Ingredient composition of concentrates was similar to the mixture used for Soya-cows in Experiment 1 (Table 1). Forage in the diet consisted of prewilted grass silage fed ad libitum (5\% orts). Details of management, methods and statistical analysis were similar to those for Soya-standard and Soya-flat cows in Experiment 1.

\section{Experiment 3}

Sixty-four cows (no primiparous) were selected from the institute's herd for this experiment, which lasted 23 weeks. They were offered roughage ad libitum (about $5 \%$ orts), consisting of prewilted grass silage and maize silage (mixed in a mix-forage wagon as 50:50 on DM-basis). In addition, concentrates were fed. For all cows level of concentrates was gradually increased from $2 \mathrm{~kg} \mathrm{~d}^{-1}$ at calving to $11 \mathrm{~kg} \mathrm{~d}^{-1}$ at day 11 . From day 11 onwards up to 21 , concentrates were fixed at $11 \mathrm{~kg} \mathrm{~d}^{-1}$. Cows were then blocked by calving date and parity and within blocks randomly assigned to one of four concentrate feeding strategies: High-Step (HS), High-Fixed (HF), Medium-Step (MS) and Medium-Fixed (MF). Level of concentrates and duration of treatment periods are shown in Table 3. In weeks 13 and 14, levels of concentrate in treatment HS and MS were changed gradually. The total amount of concentrates in week 4-23 for the High-treatment group was on average 12 and for the Low-treatment group $10 \mathrm{~kg} \mathrm{~d}^{-1} \mathrm{cow}^{-1}$. Ingredient composition of the mixtures is shown in Table 1 .

Cows were milked twice daily in a rotary parlour and individual milk yields during the experiment were recorded automatically at each milking. Further details of management and methods were similar to Experiment 1 and 2.

Variables were analysed by ANOVA according to a randomized block design with treatment factors Concentrate (high and low) and Strategy (flat and step). The average level for the first three weeks was used as covariable, except for body weight gain.

Table 3. Level of concentrates $\left(\mathrm{kg} \mathrm{d}^{-1} \mathrm{cow}^{-1}\right)$ from week 4 post partum onwards in Experiment 3.

\begin{tabular}{lllll}
\hline Period & \multicolumn{2}{l}{ Feeding strategy } & MS \\
\cline { 2 - 5 } & HS & HF & & MF \\
1. Week $4-12$ & 13 & 12 & 11 & 10 \\
2. Week 13 and 14 & $12^{\mathrm{a}}$ & 12 & $10 \mathrm{a}$ & 10 \\
3. Week $15-23$ & 11 & 12 & 9 & 10 \\
Average week $4-23$ & 12 & 12 & 10 & 10 \\
\hline
\end{tabular}

a On average. 


\section{Results}

\section{Chemical composition of feeds}

Chemical composition and feeding value characteristics of concentrate mixtures and roughages are presented in Table 4 . Differences in chemical composition of concentrates in Experiments 1 and 2 were small. As planned, protein content of the concentrate mix in Experiment 3 was higher because of the lower crude protein in the roughage part of the diet in Experiment 3 (grass silage and maize silage) as compared to Experiments 1 and 2 (grass silage only). Crude fibre content in the mixture of Experiment 3 was higher because of the use of soybean hulls and palmkernel expeller as ingredients (Table 1). The main difference in the grass silages between experiments was in crude fibre content, which was remarkably low in Experiment 2. Mean cutting date of the grass for the silages in Experiment 2 was 20 May, as compared to 24 June and 3 July in Experiment 1 and 3, respectively, which can partly explain the difference.

\section{Experiment $I$}

One cow in the Soya-flat group produced abnormally little milk without showing clear indications of illness. Nevertheless, it was decided to keep her out of the analysis. There were some cases of mastitis during the experiment in all treatment groups. Severe mastitis was the reason for exclusion of five cows: two in group Fishstandard and one in each of the remaining three groups.

Feed intake. Results of the statistical analysis of Experiment 1 are shown in Table 5. There were no indications for an interaction between feeding strategy and concentrate mixture, so only main effects are given. Mean concentrate intake over week 4-24 on standard feeding did not precisely fit the average amount of the flat level

Table 4. Chemical composition and feeding value characteristics of feeds in the experiments.

\begin{tabular}{|c|c|c|c|c|c|c|c|c|}
\hline & \multicolumn{4}{|c|}{ Concentrate mix } & \multicolumn{4}{|c|}{ Roughage } \\
\hline & \multicolumn{2}{|c|}{ Exp. 1} & \multirow[t]{2}{*}{ Exp. 2} & \multirow[t]{2}{*}{ Exp. 3} & \multirow[t]{2}{*}{ Exp. 1} & \multirow[t]{2}{*}{ Exp. 2} & \multicolumn{2}{|c|}{ Exp. 3} \\
\hline & $\mathrm{S}$ & $\mathrm{F}$ & & & & & grass & maize sil. \\
\hline Dry matter $\left(\mathrm{g} \mathrm{kg}^{-1}\right)$ & 875 & 875 & 875 & 885 & 565 & 610 & 515 & 295 \\
\hline Organic matter ( $\left.\mathrm{g} \mathrm{kg}^{-1} \mathrm{DM}\right)$ & 920 & 910 & 910 & 910 & 880 & 900 & 885 & 935 \\
\hline Crude protein $\left(\mathrm{g} \mathrm{kg}^{-1} \mathrm{DM}\right)$ & 140 & 145 & 140 & 190 & 210 & 210 & 210 & 95 \\
\hline Crude fibre $\left(\mathrm{g} \mathrm{kg}^{-1} \mathrm{DM}\right)$ & 90 & 80 & 90 & 145 & 250 & 205 & 265 & 225 \\
\hline Ether extract ( $\left.\mathrm{g} \mathrm{kg}^{-1} \mathrm{DM}\right)$ & 40 & 45 & 40 & 35 & NA & NA & NA & NA \\
\hline Ash $\left(\mathrm{g} \mathrm{kg}^{-1} \mathrm{DM}\right)$ & 80 & 90 & 90 & 90 & 120 & 100 & 115 & 65 \\
\hline $\operatorname{VEM}\left(\mathrm{kg}^{-1} \mathrm{DM}\right)$ & 1105 & 1145 & 1095 & 1050 & 865 & 980 & 840 & 860 \\
\hline Dig. crude protein ( $\left.\mathrm{g} \mathrm{kg}^{-1} \mathrm{DM}\right)$ & 105 & 110 & 105 & 150 & 150 & 160 & 155 & 55 \\
\hline $\mathrm{d}_{\mathrm{OM}}$ in vitro $(\%)$ & - & - & - & - & 74.8 & 80.2 & 73.9 & 71.7 \\
\hline
\end{tabular}


Table 5. Feed intake and production data of Experiment $1(n=29)$. Adjusted means for weeks 4-24.

\begin{tabular}{|c|c|c|c|c|c|c|}
\hline & \multicolumn{2}{|l|}{ Strategy } & \multicolumn{2}{|c|}{ Concentrate } & \multicolumn{2}{|c|}{ Significance of difference } \\
\hline & standard & flat & soya & fish & strategy & concentrate \\
\hline \multicolumn{7}{|l|}{ Milk production } \\
\hline milk $\left(\mathrm{kg} \mathrm{cow}^{-1} \mathrm{~d}^{-1}\right)$ & 26.9 & 27.1 & 26.5 & 27.5 & ns & ns \\
\hline $4 \%$ FCM $\left(\mathrm{kg} \mathrm{cow}^{-1} \mathrm{~d}^{-1}\right)$ & 26.8 & 27.0 & 26.7 & 27.0 & ns & ns \\
\hline \multicolumn{7}{|l|}{ Milk composition } \\
\hline fat content $(\%)$ & 3.97 & 3.98 & 4.04 & 3.91 & ns & $P<0.01$ \\
\hline protein content $(\%)$ & 3.20 & 3.11 & 3.15 & 3.15 & $P<0.01$ & ns \\
\hline \multicolumn{7}{|l|}{ Fat and protein production } \\
\hline fat $\left(g_{\operatorname{cow}}^{-1} \mathrm{~d}^{-1}\right)$ & 1068 & 1076 & 1074 & 1070 & ns & ns \\
\hline protein $\left(g \operatorname{cow}{ }^{-1} d^{-1}\right)$ & 862 & 838 & 836 & 863 & ns & ns \\
\hline \multicolumn{7}{|l|}{ Body weight } \\
\hline body weight gain $\left(\mathrm{kg} \mathrm{cow}^{-1}\right)^{\mathrm{a}}$ & 0.0 & -2.4 & -0.4 & -2.0 & ns & $\mathrm{ns}$ \\
\hline \multicolumn{7}{|l|}{ Feed intake } \\
\hline concentrates $\left(\mathrm{kg} \mathrm{DM}\right.$ cow $\left.-1 \mathrm{~d}^{-1}\right)$ & 10.9 & 10.0 & 10.4 & 10.6 & - & - \\
\hline roughage $\left(\mathrm{kg} \mathrm{DM} \operatorname{cow}^{-1} \mathrm{~d}^{-1}\right)$ & 8.3 & 8.7 & 8.5 & 8.5 & ns & ns \\
\hline $\operatorname{kVEM}\left(\operatorname{cow}^{-1} \mathrm{~d}^{-1}\right)$ & 19.5 & 18.6 & 18.8 & -19.3 & $P<0.01$ & ns \\
\hline \multicolumn{7}{|l|}{ Gross feed efficiency } \\
\hline $4 \%$ FCM (kg kVEM $\left.{ }^{-1}\right)$ & 1.38 & 1.45 & 1.42 & 1.40 & $P<0.05$ & ns \\
\hline
\end{tabular}

a Mean difference in body weight between week $23 / 24$ and $2 / 3$.

group. The latter was estimated at forehand on the basis of the expected average milk yield and roughage intake during the experimental period. Actual concentrate amount on standard feeding however was $0.9 \mathrm{~kg} \mathrm{DM} \mathrm{d}^{-1}$ cow $^{-1}$ higher than expected. This was coupled with only an insignificantly lower roughage intake, and so mean VEM intake in this experiment was higher on standard feeding.

DM intake from roughage and concentrates was almost identical on the soya and fishmeal diet. Total VEM intake tended to be higher on the latter diet in consequence of the higher energy value of the fishmeal concentrate as compared to the soya-mixture.

Milk production. Differences in production between standard and flat level feeding during week 4-24 were small and not significant. Differences in milk composition were also small, although milk protein content was significantly lower on flat feeding than on standard feeding $(P<0.01)$.

In both groups, average energy intake over the total experimental period was above requirements. It is reasonable to assume that the lower apparent gross feed efficiency of the standard feeding in this experiment (defined as $\mathrm{kg} 4 \% \mathrm{FCM}$ per 1000 VEM or kVEM) was likely a result of the higher VEM intake as compared to the flat level group. 
Milk yield during the first part of the experiment (week 5-14) tended to be higher when cows were on standard feeding (30.4 vs $29.7 \mathrm{~kg} \mathrm{~d}^{-1}$, but the difference was not significant. However, persistency of milk yield from week 5 onwards was significantly improved on flat level feeding $(P<0.01)$ : reduction in yield was 0.55 and 0.73 $\mathrm{kg} \mathrm{wk}^{-1} \mathrm{cow}^{-1}$ for flat level and standard feeding respectively.

In the first half of the experiment, fat content tended to be higher on flat feeding ( 3.98 vs $3.89 \%$ ); however, in the second part fat content was significantly lower (3.96 vs $4.06 \% ; P<0.05$ ), resulting in an almost equal fat content over the total experimental period ( 3.98 vs $3.97 \%$ ). Protein content was lower on flat feeding during week 4-15 (3.03 vs $3.13 \%)$ and continued to be so during the second half of the experiment ( 3.19 vs $3.29 \% ; P<0.01)$.

Milk production tended to be higher with the fishmeal than with the soya concentrate mixture $(P=0.06)$, but milkfat content was lower $(P<0.01)$, resulting in almost equal yields of $4 \% \mathrm{FCM}$. The reason of the lower milkfat content is not quite clear. One might speculate about a difference in saturation between the fats in soybeanmeal and fishmeal, but this composition was not analysed.

\section{Experiment 2}

Severe mastitis was the main reason for omitting three Soya-standard and two Soyaflat cows from the analysis. Adjusted means and indications for treatment effects of the remaining cows are presented in Table 6.

Feed intake. Contrary to Experiment 1, average actual amount of concentrates on standard feeding in Experiment 2 turned out to be lower than expected at forehand, as a result of the high quality of the roughage used in the trial. The lower concentrate intake coincided with a significantly higher roughage intake, resulting in an equal calculated net energy intake on both strategies. Energy intake was above requirements when averaged over the total experiment. The difference in feed efficiency was small and in line with the difference in body weight changes between treatments.

Milk production. Differences in production and composition of milk between standard and flat level feeding during week 4-24 were small and not significant. Milk yield during the first part of the experiment (week 5-14) tended to be higher when cows were on standard feeding (31.9 vs $30.9 \mathrm{~kg} \mathrm{~d}^{-1} \mathrm{cow}^{-1}$ ) but the difference was not significant and disappeared during the second part of the experiment. In the latter part, mean milk yield was 26.4 and $26.3 \mathrm{~kg} \mathrm{~d}^{-1} \mathrm{cow}^{-1}$ for standard and flat feeding, respectively and production of $4 \%$ FCM was $26.6 \mathrm{~kg}$ on both strategies. Reduction in milk yield was 0.46 and $0.54 \mathrm{~kg} \mathrm{wk}^{-1} \mathrm{cow}^{-1}$ for flat level and standard cows, respectively. So again, persistency tended to improve on flat level feeding but the difference in this experiment was not statistically significant.

Differences in milk composition in the first and second part of the trial were small. These smaller differences between strategies as compared to Experiment 1 might be explained by the high quality of the grass silage in Experiment 2 . 
Table 6. Feed intake and production data of Experiment 2. Adjusted means for weeks 4-24.

\begin{tabular}{|c|c|c|c|}
\hline & \multicolumn{2}{|l|}{ Strategy } & \multirow{2}{*}{$\begin{array}{l}\text { Significance } \\
\text { of difference }\end{array}$} \\
\hline & $\begin{array}{l}\text { standard } \\
(n=13)\end{array}$ & $\begin{array}{l}\text { flat } \\
(n=14)\end{array}$ & \\
\hline \multicolumn{4}{|l|}{ Milk production } \\
\hline milk $\left(\mathrm{kg} \mathrm{cow}^{-1} \mathrm{~d}^{-1}\right)$ & 29.3 & 28.8 & ns \\
\hline $4 \%$ FCM $\left(\mathrm{kg} \mathrm{cow}^{-1} \mathrm{~d}^{-1}\right)$ & 29.5 & 29.1 & ns \\
\hline \multicolumn{4}{|l|}{ Milk composition } \\
\hline fat content $(\%)$ & 4.08 & 4.05 & ns \\
\hline protein content $(\%)$ & 3.20 & 3.21 & ns \\
\hline \multicolumn{4}{|l|}{ Fat and protein production } \\
\hline fat $(g \operatorname{cow}-1 \mathrm{~d}-1)$ & 1188 & 1168 & ns \\
\hline protein $\left(\mathrm{g} \mathrm{cow}^{-1} \mathrm{~d}^{-1}\right)$ & 932 & 920 & ns \\
\hline \multicolumn{4}{|l|}{ Body weight } \\
\hline body weight gain $(\mathrm{kg} \mathrm{cow}-1)^{a}$ & -5.8 & 14.3 & $P<0.05$ \\
\hline \multicolumn{4}{|l|}{ Feed intake } \\
\hline concentrates (kg DM cow ${ }^{-1} \mathrm{~d}^{-1}$ ) & 8.6 & 10.0 & - \\
\hline roughage $\left(\mathrm{kg} \mathrm{DM} \mathrm{cow}^{-1} \mathrm{~d}^{-1}\right)$ & 11.2 & 9.6 & $P<0.01$ \\
\hline $\operatorname{kVEM}\left(\operatorname{cow}^{-1} \mathrm{~d}^{-1}\right)$ & 20.4 & 20.4 & ns \\
\hline \multicolumn{4}{|l|}{ Gross feed efficiency } \\
\hline $4 \%$ FCM (kg kVEM $\left.{ }^{-1}\right)$ & 1.46 & 1.41 & ns \\
\hline
\end{tabular}

a Mean difference in body weight between week $23 / 24$ and $2 / 3$.

\section{Experiment 3}

One cow in each of the medium concentrate groups (MS and MF) had to be withdrawn from the experiment for health reasons. Table 7 contains results from the statistical analysis. There was no interaction between strategy and concentrate level, so only main effects are given.

Feed intake. Mean levels of concentrates on both strategies were forced at forehand to be equal by the design of the experiment. This resulted in an equal intake of roughage and a similar energy intake on both strategies (Table 7). Level of concentrates had an effect on intake of roughage but the effect was smaller than expected and not significant $(P=0.07)$.

Milk production. Tendencies in production of milk, milk fat and milk protein were in favour of the flat level treatment, both with high as well as with medium level of concentrates.

Effects of level of concentrates on $4 \% \mathrm{FCM}$ and on milk composition were in favour of the higher level. The higher level also improved body weight gain, but this 
Table 7. Feed intake and production data of Experiment $3(n=31)$. Adjusted means for weeks 4-23.

$\begin{array}{llll}\text { Strategy } & \text { Concentrate level } & & \text { Significance of difference } \\ \text { step flat } & \text { high medium } & \text { strategy } \begin{array}{l}\text { concentrate } \\ \text { level }\end{array}\end{array}$

Milk production

milk $\left(\mathrm{kg} \mathrm{cow}^{-1} \mathrm{~d}^{-1}\right)$

$4 \%$ FCM $\left(\mathrm{kg} \mathrm{cow}^{-1} \mathrm{~d}^{-1}\right)$

$\begin{array}{llllll}26.2 & 26.7 & 26.9 & 26.0 & \text { ns } & P<0.05 \\ 28.0 & 28.5 & 28.8 & 27.7 & \text { ns } & P<0.01\end{array}$

Milk composition

fat content $(\%)$

protein content $(\%)$

$\begin{array}{llllll}4.46 & 4.46 & 4.49 & 4.42 & \mathrm{~ns} & \mathrm{~ns} \\ 3.28 & 3.26 & 3.31 & 3.23 & \mathrm{~ns} & P<0.01\end{array}$

Fat and protein production

fat $\left(\mathrm{g} \mathrm{cow}^{-1 \mathrm{~d}-1)} \quad 1168\right.$

protein $(\mathrm{g}$ cow $-1 \mathrm{~d}-1)$

$\begin{array}{rrrrrl}1168 & 1188 & 1204 & 1150 & \text { ns } & P<0.01 \\ 858 & 870 & 886 & 841 & \text { ns } & P<0.001\end{array}$

Body weight

body weight gain $\left(\mathrm{kg} \mathrm{cow}^{-1}\right)^{\mathrm{a}}$

19.

16.9

25.1

$10.6 \mathrm{~ns}$

$P<0.05$

Feed intake

concentrates (kg DM cow-1 $\mathrm{d}^{-1}$ )

roughage ( $\mathrm{kg} \mathrm{DM} \mathrm{cow}^{-1} \mathrm{~d}-1$ )

kVEM (cow-1 $\left.\mathrm{d}^{-1}\right)$

$\begin{array}{rrrrll}9.7 & 9.8 & 10.5 & 8.9 & - & - \\ 10.7 & 10.7 & 10.5 & 10.9 & \text { ns } & \text { ns } \\ 19.2 & 19.4 & 20.0 & 18.6 & \text { ns } & P<0.001\end{array}$

Gross feed efficiency

$4 \%$ FCM (kg kVEM-1)

$\begin{array}{llll}1.46 & 1.47 & 1.44 & 1.49\end{array}$

$P<0.05$

a Mean difference in body weight between week $22 / 23$ and $2 / 3$.

was coupled with a slightly lower apparent gross feed efficiency. Mean response of extra concentrates on production during the total experimental period was $0.53 \mathrm{~kg}$ $4 \%$ FCM kg-1 concentrates. Effects of concentrate level in early lactation on roughage, milk production and body weight change are given in Table 8 . Differences between the higher and lower feeding levels were significant (roughage intake, VEM intake, protein production, body weight gain, gross feed efficiency) or approached significancy (milk production, fat production). The response of $4 \% \mathrm{FCM}$ production on extra concentrates was approximately $0.35 \mathrm{~kg} \mathrm{~kg}^{-1}$ concentrates. The substitution of roughage by concentrates tended to be highest in early lactation with the highest level of concentrates.

\section{Discussion}

The rations in this study resembled practical rations in the Netherlands, e.g. they included prewilted grass silage (or a mixture of grass and maize silage), and large quantities of concentrates. The results confirmed the conclusions of Gordon (1976, 1977), Ostergaard (1979), and Steen \& Gordon (1980a, 1980b). So, on these typical Dutch rations, flat level feeding of concentrates resulted also in an almost equal 
Table 8. Feed intake and production data during week 4-12 of Experiment 3. Adjusted means and mean standard error of difference (MSED).

\begin{tabular}{|c|c|c|c|c|c|}
\hline & \multicolumn{4}{|c|}{ Concentrate level $(\mathrm{kg})$} & \multirow[t]{2}{*}{ MSED } \\
\hline & 13 & 12 & 11 & 10 & \\
\hline \multicolumn{6}{|l|}{ Milk production } \\
\hline milk $\left(\mathrm{kg} \mathrm{cow}^{-1} \mathrm{~d}^{-1}\right)$ & 29.6 & 29.8 & 28.9 & 28.7 & 0.54 \\
\hline $4 \%$ FCM $\left(\mathrm{kg} \mathrm{cow}^{-1} \mathrm{~d}^{-1}\right)$ & 31.5 & 31.5 & 30.5 & 30.4 & 0.59 \\
\hline \multicolumn{6}{|l|}{ Milk composition } \\
\hline fat $(\%)$ & 4.42 & 4.42 & 4.36 & 4.41 & 0.745 \\
\hline protein $(\%)$ & 3.23 & 3.20 & 3.13 & 3.09 & 0.380 \\
\hline \multicolumn{6}{|l|}{ Fat and protein production } \\
\hline fat $(g \operatorname{cow}-1 d-1)$ & 1309 & 1308 & 1259 & 1265 & 27.6 \\
\hline protein $\left(\mathrm{g} \mathrm{cow}^{-1} \mathrm{~d}^{-1}\right)$ & 953 & 945 & 906 & 892 & 16.1 \\
\hline \multicolumn{6}{|l|}{ Body weight } \\
\hline body weight gain $\left(\mathrm{kg} \mathrm{cow}^{-1}\right)^{\mathrm{a}}$ & 17.3 & 14.4 & 2.7 & 2.1 & 5.57 \\
\hline \multicolumn{6}{|l|}{ Feed intake } \\
\hline concentrates $\left(\mathrm{kg} \mathrm{DM} \operatorname{cow}^{-1} \mathrm{~d}-1\right)$ & 11.5 & 10.6 & 9.7 & 8.9 & 0.26 \\
\hline roughage $\left(\mathrm{kg} \mathrm{DM}^{\mathrm{cow}} \mathrm{cos}^{-1} \mathrm{~d}^{-1}\right)$ & 10.3 & 10.8 & 10.8 & 11.0 & 0.28 \\
\hline $\operatorname{kVEM}\left(\operatorname{cow}-1 d^{-1}\right)$ & 20.7 & 20.4 & 19.4 & 18.7 & - \\
\hline \multicolumn{6}{|l|}{ Gross feed efficiency } \\
\hline $4 \%$ FCM (kg kVEM -1$)$ & 1.52 & 1.55 & 1.57 & 1.63 & 0.024 \\
\hline
\end{tabular}

a Mean difference in body weight between week $11 / 12$ and $1 / 2$.

milk production per group if it was compared with a convential system, in which cows were fed according to their individual milk production. There are however some prerequisites: one should compare similar quantities of concentrates per strategy over the time concerned, and roughage has to be fed ad libitum. The latter might be the reason why the recent results of flat level feeding are not in line with the majority of results in studies from before 1970. In most of these studies (see Broster, 1972) animals were given a basal diet consisting of a fixed allocation of roughage, without the opportunity to compensate by an extra consumption of roughage when concentrate allowance was decreased. On rations with roughage offered ad libitum, limiting the amount of concentrates does increase the voluntary intake of roughage, particularly so in early lactation (Ekern, 1972; Journet \& Remond, 1976) and when large amounts of concentrates are fed. It is widely accepted that the substitution rate (the depression in intake of forage dry matter by an increase in the intake of dry matter from concentrates) increases with level of concentrates (Østergaard, 1979; Broster \& Thomas, 1981) and with increasing quality (digestibility) of roughage (Kirchgessner \& Schwarz, 1984; Bines, 1985; Jarrige et al., 1986). Consequently, the difference in total energy intake is much less than the additional energy supplied from the extra concentrates. And the more so, if the level 
of concentrates is higher, or the quality of roughage is better. This suggests that the system of flat level feeding improves with increasing overall planes of nutrition (Leaver, 1986).

Data published in the last 10 years also indicate that residual effects of higher concentrate levels in early lactation are not likely to occur when in winter forage is fed ad libitum (Gordon \& Steen, 1980; Thomas et al., 1981), or when in the succeeding pasture period cows can graze at generous herbage allowances (Le Du et al., 1979; Poole, 1987). Total lactation data of our experimental cows, as derived from the Central Milkrecording Service during the year of experiment, appears to confirm this (Table 9). It may explain the results of flat level feeding in our trials and in those of several others in recent literature (Gordon, 1982; Moisy \& Leaver, 1986; Poole, 1987; Andries et al., 1988; Leaver, 1988).

Some concern for production has been given to flat feeding of concentrates when forage of medium or low quality is fed (Meijer, 1985; pers. comm.). However, in a comparison of a flat rate with a step system of concentrates for cows offered two qualities of grass silage ad libitum (Taylor \& Leaver, 1984), no significant strategy effects were found on average milk production with either quality of silage. Quality of silage appeared to have a significant effect on production, however with either strategy. In our trial with moderate quality grass silage (Experiment 1), the only sig-

Table 9. Total lactation data (approx. 305 days) as derived from the Central Milk Recording Service.

\begin{tabular}{|c|c|c|}
\hline & \multicolumn{2}{|l|}{ Strategy } \\
\hline & standard & flat \\
\hline \multicolumn{3}{|l|}{ Experiment 1} \\
\hline Milk (kg) & 6719 & 6753 \\
\hline Fat $(\%)$ & 4.16 & 4.17 \\
\hline Protein $(\%)$ & 3.36 & 3.28 \\
\hline \multicolumn{3}{|l|}{ Experiment 2} \\
\hline Milk (kg) & 7141 & 6971 \\
\hline Fat $(\%)$ & 4.30 & 4.27 \\
\hline Protein $(\%)$ & 3.32 & 3.24 \\
\hline \multicolumn{3}{|c|}{ Experiment 3, high level } \\
\hline Milk (kg) & 7084 & 7062 \\
\hline Fat $(\%)$ & 4.62 & 4.70 \\
\hline Protein $(\%)$ & 3.43 & 3.44 \\
\hline \multicolumn{3}{|c|}{ Experiment 3, medium level } \\
\hline Milk (kg) & 6943 & 7049 \\
\hline Fat $(\%)$ & 4.56 & 4.55 \\
\hline Protein $(\%)$ & 3.37 & 3.36 \\
\hline
\end{tabular}


nificant strategy effect was on milk protein content, which was $0.1 \%$-unit reduced on the flat level system.

Some concern to flat level feeding has also been given for fertility (Taylor \& Leaver, 1984; Poole, 1987), as the system of flat rate feeding in early lactation normally will result in a greater mobilization of body fat as compared to standard feeding. The figures in Table 8 show that the level of concentrates in early lactation had a relatively small effect on milk yield and $4 \%$ FCM production. The effect was mainly on milk protein content and body weight. This suggests that cows on the lower level of concentrates mobilized more body fat for energy utilization, and that protein was limited. Conception rates may be reduced when cows at the time of service heavily draw on body fat reserves (Butler \& Smith, 1989). Calving intervals of cows in our trials, being 386 and 374 days in Experiment 1 and 361 and 376 days in Experiment 2 for standard and flat feeding, respectively, gave no conclusive evidence for that concern. Poole (1987) found higher proportions of cows not conceiving within a limited breeding period, when a flat rate feeding system was employed with a medium level of $7.1 \mathrm{~kg} \mathrm{DM}$ of concentrates $\operatorname{cow}^{-1} \mathrm{~d}^{-1}$ in addition to a low quality silage (approx. $750 \mathrm{VEM} \mathrm{kg}^{-1} \mathrm{DM}$ ) fed ad libitum. In the experiment of Taylor \& Leaver (1984), calving intervals were significantly different between high- and low-quality silage groups, but not so between strategies. However, mean interval was longest of cows on the low quality silage with flat feeding. This also showed the greatest loss of condition score in early lactation. With low quality silages, they recommend to pay attention to the selection of an adequate concentrate level when flat feeding is practicised, by preventing condition scores falling too far in early lactation. Indications for amounts are given by Leaver (1988).

From the experiments it is concluded, that with group feeding of roughages offered ad libitum, there is no need to feed high-yielding cows with concentrates strictly to their estimated individual energy requirements. This may be of increasing importance when roughage can be fed ad libitum on more farms, as a consequence of diminishing number of cows per farm.

\section{References}

Andries, J. A., D. L. de Brabander \& F. X. Buysse, 1988. Feeding strategies for dairy cattle. Comparison of flat rate feeding and standard feeding during early lactation. Archiv für Tierernährung 38: 651-661.

Bines, J. A., 1985. Feeding systems and food intake by housed dairy cows. Proceedings of the Nutrition Society 44: 355-362.

Broster, W. H., 1972. Effect on milk yield of the cow of the level of feeding during lactation. Dairy Science Abstracts 34: 265-288.

Broster, W. H. \& C. Thomas, 1981. The influence of level and pattern of concentrate input on milk output. In: W. Haresign (Ed.), Recent advances in animal nutrition-1981, p. 49-69. Butterworths, London.

Broster, W. H., V. J. Broster \& T. Smith, 1969. Experiments on the nutrition of the dairy heifer. VIII. Effect on milk production of level of feeding at two stages of the lactation. Journal of Agricultural Science (Cambridge) 72: 229-245.

Broster, W. H., V. J. Broster, T. Smith \& J. W. Siviter, 1975. Experiments on the nutrition of the dairy heifer. IX. Food utilization in lactation. Journal of Agricultural Science (Cambridge) 84: 173-186. 


\section{Y. S. RIJPKEMA, L. VAN REEUWIJK AND P. W. GOEDHART}

Butler, W. R. \& R. D. Smith, 1989. Interrelationships between energy balance and postpartum reproductive function in dairy cattle. Journal of Dairy Science 72: 767-783.

CVB, 1979. Short table on feeding standards for farm animals and nutritive value of feedstuffs. (In Dutch.) Centraal Veevoederbureau in Nederland, Lelystad. $33 \mathrm{pp}$.

Chalmers, J. S., F. R. Moisey \& J. D. Leaver, 1984. The performance of dairy cows with access to selffeed silage offered concentrates from a free-access dispenser. Animal Production 39: 17-24.

Ekern, A., 1972. Feeding of high yielding dairy cows III. Roughage intake in high yielding cows when fed grass silage ad libitum. Meldinger fra Norges Landbrukshøgskole 51: nr. 32.

Es, A. J. H. van, 1978. Feed evaluation for ruminents. I. The systems in use from May 1977 onwards in the Netherlands. Livestock Production Science 5: 331-345.

Gordon, F. J., 1976. Effect of concentrate level and stocking rate on performance of dairy cows calving in late winter. Animal Production 22: 175-187.

Gordon, F. J., 1977. The effect of three concentrate input levels on the performance of dairy cows calving during mid-winter. Animal Production 25: 373-379.

Gordon, F. J., 1982. The effect of pattern of concentrate allocation on milk production from autumncalving heifers. Animal Production 34: 55-61.

Jarrige, R., C. Demarquilly, J. P. Dulphy, A. Hoden, J. Robelin, C. Beranger, Y. Geay, M. Journet, C. Malterre, D. Micol \& M. Petet, 1986. The INRA 'Fill Unit' system for predicting the voluntary intake of forage-based diets in ruminants: a review. Journal of Animal Science 63: 1737-1758.

Johnson, C. L., 1977. The effect of the plane and pattern of concentrate feeding on milk yield and composition in dairy cows. Journal of Agricultural Science (Cambridge) 88: 79-94.

Journet, M. \& B. Remond, 1976. Physiological factors affecting the voluntary intake of feed by cows: a review. Livestock Production Science 3: 129-146.

Kirchgessner, M. \& F. J. Schwarz, 1984. Einflussfaktoren auf die Grundfutteraufnahme bei Milchkühen. Übersichten der Tierernährung 12: 187-214.

Le Du, Y. L. P., J. Combellas, J. Hodgson \& R. D. Baker, 1979. Herbage intake and milk production by grazing dairy cows. 2 . The effects of level of winter feeding and daily herbage allowance. Grass and Forage Science 34: 249-260.

Leaver, 1988. Level and pattern of concentrate allocation to dairy cows. In: P. C. Garnsworthy (Ed.), Nutrition and lactation in the dairy cow, p. 315-326. Butterworths, London.

Leaver, J. D., 1986. Systems of concentrate distribution. In: W. H. Broster, R. H. Phipps \& C. L. Johnson (Eds), Principles and practice of feeding dairy cows, p. 113-131. NIRD Technical Bulletin 8, Reading University.

Moisey, F. R. \& J. D. Leaver, 1985. Systems of concentrate allocation for dairy cattle. 3. A comparison of flat-rate feeding systems at two amounts of concentrates. Animal Production 40: 209-217.

$\emptyset$ stergaard, V., 1979. Strategies for concentrate feeding to attain optimum feeding level in high yielding dairy cows. Report 482. National Institute of Animal Science, Copenhagen.

Poole, D. A., 1987. Flat v. step feeding of medium or high levels of concentrates for dairy cows. Animal Production 45: 335-344.

Steen, R. W. J. \& F. J. Gordon, 1980a. The effect of level of concentrate allocation to January/February calving cows on total lactation performance. Animal Production 30: 39-51.

Steen, R. W. J. \& F. J. Gordon, 1980b. The effect of type of silage and level of concentrate supplementation offered during early lactation on total lactation performance of January/February calving cows. Animal Production 30: 341-354.

Taylor, W. \& J. D. Leaver, 1984. Systems of concentrate allocation for dairy cows. 2. A comparison of two patterns of allocation for autumn calving cows of fered two qualities of grass silage ad libitum. Animal Production 39 :325-333.

Taylor, W. \& J. D. Leaver, 1986. Systems of concentrate allocation for dairy cattle. 4. A comparison of two amounts and two patterns of allocation. Animal Production 43: 17-36.

Tilley, J. M. A. \& R. Terry, 1963. A two-stage technique for in-vitro digestion of forage crops. Journal of the British Grassland Society 18: 104-111. 